Toms Čevers, $M g$. iur.

Latvijas Universitāte, Latvija

\title{
KRIMINĀLLIKUMAM 20 - KRIMINĀLLIKUMA 190. PANTA “KONTRABANDA” ĢENĒZE UN EVOLŪCIJA
}

\section{YEARS AFTER ADOPTION OF THE CRIMINAL LAW OF THE REPUBLIC OF LATVIA: GENESIS AND EVOLUTION OF SECTION 190 "SMUGGLING”}

\begin{abstract}
Summary
The article follows the amendments made in part one of the Section 190 "Smuggling" of the Criminal Law of the Republic of Latvia, providing the analysis of the effect brought by the changes in the disposition of part one of the Section 190 on the comprehension of the constituent elements of smuggling, as well as an evaluation of conformity between the changes made in the sanctions of part one of the Section 190 and legislator's attitude towards harmfulness of smuggling. It is concluded that in amending the legal definition of the smuggling and criminalization threshold, the legislator has not respected the principle of legal certainty.
\end{abstract}

Atslēgvārdi: kontrabanda, kriminālatbildības slieksnis, noziedzīga nodarījuma priekšmets, tiesiskās noteiktîbas princips

Keywords: smuggling, criminalization threshold, item of a criminal offense, legal certainty

\section{Ievads}

1998. gada 17. jūnijā tika pieņemts, bet nākamā gada 1. aprīlī stājās spēkā Krimināllikums ${ }^{1}$ (turpmāk arī - KL). Tātad šogad apritējuši 20 gadi, kopš juridiski saistošs kḷuvis atjaunotās Latvijas Republikas galvenais materiālo krimināltiesību avots. N̦emot vērā, ka šajā relatīvi īsajā laika posmā valsts attīstība ir bijusi dinamiska - to skārušas dažādas sociālas, politiskas un ekonomiskas pārmaiņas, kas tieši ir ietekmējušas arī valsts tiesisko sistēmu, ir pamats aplūkot Krimināllikuma līdzšinējo pilnveidi, kas noritējusi intensīvi. Normatīvo tiesību aktu nepastāvību var atzīt par mūsdienu straujā dzives ritma noteiktu likumsakarību un attiecīgi normativo tiesību aktu grozījumu kritisku un laikus veiktu analīzi - par tiesību zinātnes izaicinājumu.

Turpmāk uzmanība veltīta konkrētāk Krimināllikuma 190. panta "Kontrabanda” genēzei un evolūcijai divu iemeslu dēl, kas likuši pārvērtēt valsts nostāju ekonomikas aizsardzības jomā. Pirmkārt, atjaunojot neatkarību 1990. gadā, vajadzēja atteikties no

Krimināllikums: LV Likums. Latvijas Vēstnesis, 1998. 8. jūlijs, Nr. 199/200; likuma "Par Krimināllikuma spēkā stāšanās un piemērošanas kārtību" (Par Krimināllikuma spēkā stāšanās un piemērošanas kārtību: LV Likums. Latvijas Vēstnesis, 1998. 4. novembris, Nr. 331/332) 1. pants. 
padomju okupācijas varas uzspiestās komunistiskās ideologijas, kas lielākoties balstijāa valsts kontrolētā ekonomikā, valsts ekskluzīvās kompetences apdraudējumu vērtējot sevišḳi jūtīgi, kas atspoguḷojās arī krimināltiesībās. Otrkārt, līdz ar pievienošanos Eiropas Savienībai 2004. gadā Latvijas Republikai bija pamats pārvērtēt muitas uzdevumus un ar to saistīto interešu krimināltiesiskās aizsardzības pietiekamību, ņemot vērā, ka reǵionālās organizācijas pastāvēšana balstās vienotā iekšējā tirgus darbībā un Latvijas Republika veido tās ārējo robežu.

Krimināllikuma 190. panta pirmā daḷa līdz šim grozīta, ieviešot gan konceptuālas pārmaiņas valsts krimināltiesiskajā politikā, gan arī tieši kontrabandas formulējuma un tās krimināltiesiskā novērtējuma izmaiṇas. Rakstā fiksēti Krimināllikuma 190. panta pirmajā daḷā izdarītie grozījumi, kā arī analizēta dispozīcijas izmaiņu ietekme uz kontrabandas noziedzīgā nodarījuma sastāva izpratni un vērtēta sankciju izmaiṇu atbilstība likumdevēja nostājai par kontrabandas kaitīgumu.

\section{Krimināllikuma 190. panta "Kontrabanda" pirmās daḷas genēze}

Pēc Latvijas Republikas neatkarības atgūšanas ar Latvijas Republikas Augstākās Padomes 1991. gada 29. augusta lēmumu "Par Latvijas PSR likumdošanas aktu piemērošanu Latvijas Republikas teritorijā” līdz jaunajiem sociālajiem, politiskajiem, ekonomiskajiem un juridiskajiem apstākḷiem atbilstoša krimināllikuma izstrādāšanai Latvijas Republikas teritorijā ar labojumiem spēku saglabāja Latvijas PSR Kriminālkodekss, kurš atbilstoši valsts konstitucionālām izmaināām tika pārdēvēts par Latvijas Kriminālkodeksu.

Latvijas Kriminālkodeksā formāli vēl neizlabojot kontrabandas grupas objektu (noziedzīgā nodarījuma sastāvs palika likuma Sevišḳās dal̦as pirmās nodaḷas "Noziegumi pret Republiku” otrajā daḷā "Citi valsts noziegumi”), 73. pants, kurā bija noteikta kriminālatbildība par kontrabandu, tika būtiski rediǵēts - turpinot ar 1961. gada 6. janvāra Latvijas PSR Kriminālkodeksu iedibināto pieeju kontrabandas pazīmju aprakstā, tika sniegta tās legāldefinīcija, atsakoties no atsauces uz muitas normatīvajiem tiesību aktiem. $^{2}$

Uzlabojot tā izteiksmi, minētais pants tika sadalīts divās daḷās: 1) pamatsastāvā bija paredzēta atbildība par preču vai citu vērtību nelikumīgu pārvietošanu pāri Latvijas Republikas muitas robežai, kas izdarīta lielos apmēros, apejot muitas kontroli vai noslēpjot no šādas kontroles, tādējādi aptverot visus gadijjumus, kad preces var šķērsot valsts muitas robežu bez muitas iestāžu ziṇas, 2) kvalificētajā sastāvā bija paredzēta atbildība par kontrabandu, ja to izdarījusi personu grupa, kura ir organizējusies, lai nodarbotos ar kontrabandu, kā arī par narkotisko līdzekḷu, stipri iedarbīgu, indīgu un radioaktīvu vielu, sprāgstvielu, ieroču un munīcijas (izn,emot gludstobra medỉbu ieroču un to munīcijas) kontrabandu, tādējādi paaugstinot atbildību par speciālu vispārēji bīstamu priekšmetu prettiesisku pārvietošanu. ${ }^{3}$

2 Latvijas Padomju Sociālistiskās Republikas Kriminālkodekss. Oficiālais teksts ar pielikumiem, kuros ievietoti pa pantiem sistematizēti materiāli. Rīga: Avots, 1984, 83. lpp.

3 Latvijas Kriminālkodekss. Rīga: Latvijas Republikas Tieslietu ministrija, 1992, 44., 45. lpp. 
Saglabājot Latvijas Kriminālkodeksa struktūru, bet krimināltiesisko institūtu izpratnē izmantojot Rietumu tiesību loka valstu krimināltiesību zinātnes atziņas un likumdošanas praksi, Krimināllikuma izstrādi virzījušas depolitizācijas, humanizācijas un dekriminalizācijas idejas. ${ }^{4}$

Koriǵējot ar kontrabandu apdraudēto interešu tvērumu, ${ }^{5}$ kriminālatbildība par kontrabandu kā ekonomiska rakstura noziedzīgo nodarījumu turpmāk tika paredzēta KL 190. pantā "Kontrabanda". Šis pants ievada Krimināllikuma 19. nodalu "Noziedzīgi nodarījumi tautsaimniecībā", taču konstatējams, ka pantu secību šajā nodaḷā nav noteikusi ne pantu nosaukumu alfabētiskā kārtỉba, ne noziedzīgo nodarỉjumu smagums. Tādēl secināms, ka, kontrabandas sastāvu ietverot kā pirmo pirms citiem tautsaimniecību apdraudošiem noziedzīgiem nodarījumiem, atspogulıjies likuma autoros nostiprinājies uzskats par kontrabandas noziedzīgā nodarījuma sastāva nozīmību, programmatiski akcentējot ar to aizskarto interešu aizsargāšanas nepieciešamību ar spēcīgāko tiesību aizsardzības līdzekli, proti, piedraudot ar kriminālatbildību.

KL 190. pantā sniegta kontrabandas legāldefinīcija, kuras būtība ir saglabājusies līdz šim brīdim, proti, kā preču vai citu vērtību pārvietošana pāri Latvijas Republikas muitas robežai, apejot muitas kontroli vai noslēpjot preces vai citas vērtības no šādas kontroles, vai izmantojot viltotus muitas vai citus dokumentus, vai citādā nelikumīgā veidā.

Izvēlētais legāldefinīcijas formulējums ir aprakstošāks salīdzinājumā ar Latvijas Kriminālkodeksā ietverto, jo uzskaita preču prettiesiskās pārvietošanas veidus pāri Latvijas Republikas muitas robežai, maldinot par tiesību normas tvērumu, jo pārvietošanas veidu uzskaitījums ir iesākts ar konkrētiem piemēriem, bet galu galā nav pabeigts. Likumdevēja norāde, ka preču prettiesiska pārvietošana, neraugoties uz izvēlēto veidu, veido kontrabandu, ir pietiekama, lai atsevišķu noziedzīgā nodarījuma sastāva elementu iztulkošanu tālāk uzticētu tiesību doktrīnas veidotājiem un praktiķiem. Nākotnē tikai pilnveidojoties muitas formalitātēm un mērķtiecigākām kḷ̂ūstot arī noziedzības stratēgijām, nav iespējams prognozēt noziedzīgā nodarìjuma izdarišsanas veidus, kādēl tiesību normas iespējami vienkāršotai piemērošanai nav lietderīgi noteikt tās tvēruma ierobežojumus, kas būtiski neietekmē izdarīta noziedzīgā nodarījuma kaitīgumu.

Likumdevējs, sniedzot prettiesiskā nodarījuma aprakstu, izvēlējies aprakstošas dispozīcijas veidu, nosaucot noziedzīgo nodarījumu un aprakstot tā pazimes. ${ }^{6}$ Kaut

4 Niedre A. Par Latvijas krimināltiesībām, tuvojoties Eiropas kritērijiem. Latvijas Vēstnesis, 2001. gada 9. janvāris, Nr. 4. Pieejams: https://www.vestnesis.lv/ta/id/1311 [aplūkots 2019. gada 4. maijā]; Krastiņ̌̌ U. Krimināllikumam 10 gadi: tapšana, attīstība un perspektīva. No: Juridiskā zinātne, 2010, Nr. 1, 7.-8. lpp.

5 Tirgus ekonomikas principos balstītā tautsaimniecībā, nenoliedzot kontrabandas negatīvo ietekmi uz valsts iekšējo tirgu un valsts budžeta izpildi, kontrabanda nav uzskatāma par valsts ārējās tirdzniecības monopola graušanu un tā eksaltēti netiek interpretēta kā kaitējums valsts saimnieciskajai varenībai (sk. kontrabandas novērtējumu padomju krimināltiesībās: Blūma M., Reigase A. Latvijas PSR Kriminālkodekss un tā attīstība. Rīga: Pētera Stučkas LVU Redakcijas un izdevniecibas daļa, 1972, 54. lpp.). Atsakoties no kareivīga patosa normatīvo tiesību aktu izstrādē, Krimināllikuma struktūra nepārprotami liecina par rūpēm aizsargāt valsts ekonomikas intereses, nevis - valsts politikas ideolog̣iskās nostādnes.

6 Krastinš̌ U., Liholaja V., Niedre A. Krimināltiesības. Vispārīgā daļa. Trešais papildinātais izdevums. U. Krastinšs (zin. red.). Rīga: Tiesu namu aǵentūra, 2008, 29. lpp. 
arī Krimināllikuma izstrādes laikā muitas lietas detalizēti regulēja Muitas likums ${ }^{7}$, kurā bija noteikta arī preču pārvietošanas kārtība, kuras pārkāpums ir kontrabandas pamatā, likumdevējs KL 190. pantu neizvēlējās formulēt, piemēram, kā preču lielā apmērā pārvietošanas kārtības pārkāpumus. Nemot vērā, ka Krimināllikumā pilnībā sniegt noziedzīgā nodarījuma pazīmes ir raksturīgi nopietnāko noziedzīgo nodarījumu gadỉjumos, nepaļaujoties uz saistītā tiesiskā regulējuma izmaiṇām, atzīstams, ka likumdevēja ieskatā kontrabanda bija gana būtisks pārkāpums. Kritiski gan vērtējams, vai tas guvis atspoguḷojumu arī sankcijās, kas vērtēts raksta turpinājumā.

Šāda likumdevēja izškłiršanās liecina par ieceri izslēgt šaubas par to, ka norma varētu būt blanketa, lai gan saskaņā ar dispozīciju kriminālatbildība paredzēta par preču pārvietošanu jebkādā nelegālā veidā, kas ietver visus muitas kārtības pārkāpumus, kuri vērsti uz preču prettiesisku pārvietošanu pāri valsts muitas robežai. Uz to cita starpā norādīts arī pirmajā apskatāmās tiesību normas zinātniskajā komentārā, citējot atbilstošo Muitas likuma regulējumu. ${ }^{8}$

Kontrabandas legāldefinīcijā ietverot visus preču prettiesiskas pārvietošanas pāri valsts muitas robežai gadījumus, netiek pievērsta uzmanība tam, ka kontrabandu nebūtu pamats konstatēt jebkurā gadījumā, kad preces tiek ievestas valsts muitas teritorijā vai izvestas no tās, pārkāpjot normatīvo tiesību aktu prasības. Piemēram, saskaṇā ar minētā Muitas likuma 3. pantu Latvijas Republikas muitas teritorija ir visa valsts teritorija, bet tās robeža ir muitas robeža. Likuma 1. panta trešajā daļā, skaidrojot brīvās zonas jēdzienu, norādīts, ka tā ir muitas teritorijas daḷa. N̦emot vērā, ka brīvajās zonās esošās preces tirdzniecības politikas pasākumu piemērošanā pielīdzināmas ārpus Latvijas Republikas muitas teritorijas esošām precēm, prettiesiska rīcība ar tām brīvo zonu robežās automātiski nenodara valstij ekonomiska rakstura kaitējumu. Lai ievērotu minēto un vienlaikus nesarežgìitu KL 190. panta pirmās daḷas dispozīcijas formulējumu, minētā tiesību norma interpretējama, no tās tvēruma izslēdzot gadijjumus, kad preces prettiesiski ievestas brīvajā zonā no trešajām valstīm.

\section{Krimināllikuma 190. panta "Kontrabanda” pirmās daļas evolūcija}

KL 190. panta pirmās daļas dispozīcija jaunā redakcijā tika izteikta ar 2005. gada 28. aprīḷa likumu "Grozījumi Krimināllikumā”. Redakcionālas izmaiṇas tika veiktas kontrabandas legāldefinīcijā, muitas robežas šķēèsošanas vietā norādot uz preču nelikumīgu ievešanu Latvijas Republikas muitas teritorijā vai izvešanu no tās [šeit un turpmāk raksta autora izcēlumi treknrakstā]. Dažādajiem formulējumiem nav būtiskas atšķirības, jo, pirmkārt, muitas teritorijā var iekḷūt un no tās var izkḷūt, tikai ş̌̉ēēsojot muitas robežu, un, otrkārt, muitas robeža vienmēr ir norobežojusi visu muitas teritoriju. Nav konstatējams, ka formulējuma izmaiṇas būtu saistāmas ar krimināltiesiskā un muitas lietas regulējošā normatīvā regulējuma saskaṇošanas nepieciešamību; savukārt

7 Muitas likums: LV Likums. Latvijas Vēstnesis, 1997. 27. jūnijs, Nr. 155/156 (zaudējis spēku).

8 Krastinš̌ U., Niedre A. Krimināllikuma komentāri. 5. grāmata. Sevišķā daḷa. Rīga: AFS, 1999, 41.42. lpp.

9 Grozijumi Krimināllikumā: LV Likums. Latvijas Vēstnesis, 2005. 18. maijs, Nr. 78. 
juridiskajā literatūrā pretrunīgi norādīts, ka attiecīgajam grozījumam piešķirama īpaša nozīme, taču nav skaidrots tā mērḳis un ietekme uz kontrabandas sastāva izpratni. ${ }^{10}$

N̦emot vērā, ka līdz ar šiem grozijjumiem izmaiṇas veiktas arī KL 190. ${ }^{1}$ panta dispozīcijā, tad šādas izvēles pamatā varētu būt iecere uzskatāmi nodalìt kriminālatbildỉbu par ekonomisko kontrabandu, kas paredzēta KL 190. pantā, no ierobežotas vai aizliegtas aprites priekšmetu kontrabandas, ņemot vērā, ka uz šiem speciālajiem priekšmetiem muitas procedūru attiecināšana nav iespējama vai ir ierobežota, kādēḷ tām ir mazāka nozīme pārvietojamo preču tiesiskā statusa noteikšanā. Taču likumdevējs, kā paskaidrots turpmāk, šādu log̣iku nav ievērojis, kādēḷ grozijjumu mērķa noskaidrošana paliek atklāta.

KL 190. ${ }^{1}$ pantā kriminālatbildība tika paredzēta par narkotisko vai psihotropo vielu vai šo vielu izgatavošanai paredzēto izejmateriālu (prekursoru), kā arī par radioaktīvo vai bīstamo vielu, stratēgiskas nozīmes preču vai citu vērtību, sprāgstvielu, ieroču, munīcijas pārvietošanu pāri Latvijas Republikas valsts robežai jebkādā nelikumīgā veidā. Sākotnēji KL 190. ${ }^{1}$ pantā bija kriminalizēta narkotisko vai psihotropo vielu vai šo vielu izgatavošanai paredzēto izejmateriālu (prekursoru) pārvietošana pāri Latvijas Republikas muitas robežai. ${ }^{11}$

Salīdzinošā aspektā, noškirot KL 190. un 190. ${ }^{1}$ panta sastāvu, pārskatāmāk būtu bijis lietot līdzīgu formulējumu, tekstā akcentējot būtiskāko atškirīibu, respektīivi, abu pantu dispozīcijās norādot vai nu teritorijas statusu, uz kuru vai no kuras preces tiek pārvietotas (attiecīgi ievešana valsts muitas teritorijā / valsts teritorijā vai izvešana no tās), vai nu šķērsotās robežas statusu (attiecīgi pārvietošana pāri valsts muitas robežai / valsts robežai)).

Kontrabandas sastāva objektīvās puses būtisks elements ir pārvietojamais noziedzīgā nodarījuma priekšmets, jo tas tieši determinē izdarītā kaitīgumu. Sākotnēji kontrabandas priekšmeta raksturošanā lietoti vārdi "preces un citas vērtỉbas", šādai pieejai būtībā saglabājoties līdz pat mūsdienām. Šāds, no vienas puses, ierobežots, bet no otras - atvērts uzskaitijums, var izraisīt neskaidrības, jo, vēršoties pret personu, vienmēr jābūt noskaidrotam, vai attiecīgais pārvietotais priekšmets ir prece vai tomēr kāda cita vērtība. Iespējams, izvēloties šādu formulējumu, likumdevējs bija iecerējis aptvert visus iespējamos gadījumus, jēdzienu "vērtỉbas" uzskatot par saturiski ietilpīgāku nekā "preces", domājams, ar preci saprotot tikai tirdzniecības kā sistemātiskas komercdarbības priekšmetu, lai gan kontrabandas kontekstā nav nozīmes ne tās izdarīšanas galīgajam mērḳiem, ne noziedzīgajā darbībā iesaistīto personu savstarpējām saistībām. Autoraprāt, nekādas domstarpības nevarētu izraisìt vienīgi jēdziena "preces"

10 Krastiņš U., Liholaja V., Niedre A. Krimināltiesības. Sevišķā daḷa. Trešais papildinātais izdevums. U. Krastiņš (zin. red.). Rīga: Tiesu namu aǵentūra, 2009, 421. lpp.

11 Ar 2002. gada 17. oktobra likumu "Grozījumi Krimināllikumā" (Grozījumi Krimināllikumā: LV Likums. Latvijas Vēstnesis, 2002. 6. novembris, Nr. 161) Krimināllikums tika papildināts ar jaunu noziedzīgā nodarījuma sastāvu, proti, ar $190 .^{1}$ pantu "Narkotisko, psihotropo vielu un šo vielu izgatavošanai paredzēto izejmateriālu (prekursoru) kontrabanda”, ar kuru atsevišķā pantā paredzēta kriminālatbildība par narkotisko vai psihotropo vielu vai šo vielu izgatavošanai paredzēto izejmateriālu (prekursoru) pārvietošanu pāri Latvijas Republikas muitas robežai, apejot muitas kontroli vai noslēpjot šĩs vielas no šădas kontroles, vai izmantojot viltotus muitas vai citus dokumentus, vai citādā nelikumīgā veidā. 
lietošana, jo, ja kāda vērtība ir deklarējama, tā arī ir uzskatāma par preci muitas lietu kontekstā. Jānorāda, ka šāds nenoteikts kontrabandas priekšmeta raksturojums sastopams jau padomju varas laikā pastāvošajā regulējumā līdz ar kontrabandas definēšanu 1961. gada 6. janvāra Latvijas PSR Kriminālkodeksā. Turklāt, jau komentējot apskatāmo KL pantu, Dr. iur. Aivars Niedre, atsaucoties uz konkrētajā laikā spēkā esošo Muitas likumu, norādījis ka "preces” jau aptver "citas vērtības”, tā kā Muitas likuma 1. panta piecpadsmitajā un devin,padsmitajā daļā ar muitošanas objektu tika saprasta prece kā jebkura kustama manta, arī valūta, vērtslietas, jebkuri enerǵijas veidi un transportlīdzekli, izṇemot komerciālos transportlīdzekḷus. ${ }^{12}$

Ar jau pieminēto 2005. gada 28. aprīla likumu "Grozījumi Krimināllikumā” tika arī precizēts kontrabandas priekšmeta nosaukums, tam pievienojot paskaidrojošus vārdus "muitošanai pakḷautās preces vai citas vērtības". Tas uzskatāms par liekvārdīgu redakcionālu papildinājumu, kas vienīgi apgrūtina normas uztveri, jo kontrabandas gadījumā kriminālatbildība iestājas par preču nelikumīgu pārvietošanu pāri valsts muitas robežai - noteiktas preču pārvietošanas prasības, kuras būtu iespējams pārkāpt, tiek paredzētas tikai tad, ja preces ir muitojamas.

No KL 190. panta tvēruma pakāpeniski tikuši izslēgti noziedzīgā nodarījuma priekšmeti, kuri nav saistāmi ar valsts tautsaimniecības apdraudējumu. Nākamais logiskais likumdevēja solis būtu kriminālatbildību par to prettiesisku starptautisku pārvietošanu iekḷaut Krimināllikuma 20. nodaḷā "Noziedzīgi nodarījumi pret vispārējo drošību un sabiedrisko kārtību”, kurā jau kriminalizēta dažāda rīcība ar tiem, piemēram, to pārvietošana, glabāšana un realizēšana, n,emot vērā, ka, izdarot speciālo priekšmetu kontrabandu, netiek tik daudz apdraudēts iekšējais tirgus un valsts ekonomiskā drošỉba, cik sabiedrības fiziskā drošỉba.

Ieviešot KL 190. ${ }^{1}$ pantu ar 2002. gada 17. oktobra likumu "Grozījumi Krimināllikumā”, atsevišķā pantā tika kriminalizēta narkotisko vai psihotropo vielu vai šo vielu izgatavošanai paredzēto izejmateriālu (prekursoru) kontrabanda. Savukārt ar 2005. gada 28. aprīla likumu "Grozījumi Krimināllikumā” šis pants turpmāk paredzēts visu speciālo priekšmetu prettiesiskas pārvietošanas kriminalizēšanai, jo tā pirmā daļa papildināta ar iepriekš KL 190. panta trešajā daḷā uzskaitītajiem speciālajiem priekšmetiem, vienīgi stipri iedarbīgās un indīgās vielas pārsaucot par bīstamām vielām. ${ }^{13}$ Šãda pieeja ne tikai sekmē Krimināllikuma pārskatāmību, kas atvieglo tā piemērošanu, bet, nodalot kriminālatbildību atsevišk,i izdalītos secīgos pantos, arī akcentē šo atšḳirīgas kategorijas priekšmetu pārvietošanas īpatnības, par ko jau minēts iepriekš. Taču, kā konstatējusi Dr. iur. Valentija Liholaja, par spīti grozījumu mērķim pastiprināt cīṇu ar šo priekšmetu nelegālu apriti izvēlētās sankcijas šo politikas iniciatīvu neatspoguloja, ${ }^{14}$ kārtējo reizi iejaucoties Krimināllikuma integritātē bez pienācīgas rūpības.

12 Krastiņš U., Niedre A., 41. lpp.

13 Niedre A. Komentārs par Krimināllikuma grozījumiem, kas izdarīit pēc 2002. gada 31. oktobra. Grām: Krimināllikums. Rìga: AFS, 2006, 176. lpp.

14 Liholaja V. Demokrātijas paraugstunda jeb Krimināllikuma kārtējā vivisekcija. Jurista Vārds, 2004. 27. janvāris, Nr. 3. Pieejams: https://juristavards.lv/doc/83479-demokratijas-paraugstunda-jebkriminallikuma-karteja-vivisekcija/ [aplūkots 07.05.2019.]; Liholaja V. Uz Krimināllikuma desmitgadi atskatoties. Jurista Vārds, 2009. 17. novembris, Nr. 46, 67. paragräfs. 
Aplūkojot turpmāk minētās likumdevēja izšķiršanās kontrabandas priekšmeta definēšanā, kas bija spēkā tikai nepilnus divarpus gadus, atkal jāpārdomā likumdevēja attieksme pret tādu juridisko kultūru ietekmējošu kvalitāti kā normatīvo tiesību aktu noteiktība, lai veicinātu sabiedrības uzticēšanos tiesībām, nekavētu tiesību piemērotāju darbu, kuriem ikreiz jāpielāgojas aktuālajām izmaiņām, un savu laiku, kas būtu veltāms sabiedrībai būtisku problēmu mērḳtiecīgai risināšanai, nevis prognozējamu kḷūdu novēršanai. ${ }^{15}$

Akcīzes preces izsenis bijis iecienīts kontrabandas priekšmets, ņemot vērā, ka to prettiesiska pārvietošana saistāma ar lielāko finansiālo ieguvumu, jo iespējams nelikumīgi izvairīties no ievērojamā akcīzes nodokḷa nomaksas. Iespējams, ar mērḳi paaugstināt sankciju par alkohola kontrabandu likumdevējs ar 2007. gada 21. jūnija likumu "Grozījumi Krimināllikumā"16 KL 190. ${ }^{1}$ panta dispozīijā expressis verbis ieklāāa līdz tam ar vispārīgo jēdzienu "preces” KL 190. panta pirmajā dạ̦ā aptverto spirtu un citus alkoholiskos dzērienus, ievērojot, ka KL 190. ${ }^{1}$ panta sankcijas bija bargākas par KL 190. pantā paredzētajām. Tādā gadỉjumā neatbildēts paliek jautājums, kādēl līdztekus tam KL 190. ${ }^{1}$ panta tvērumā netika iekḷauti arī tabakas izstrādājumi, kuru nelikumiga starptautiska transportēšana arī ir ienesīga.

Ievērojot šì regulējuma acīmredzami nepārdomātu raksturu, stājoties spēkā 2009. gada 19. novembra likumam "Grozījumi Krimināllikumā"17, no KL 190. ${ }^{1}$ panta noziedzịgā nodarījuma priekšmetu klāsta jau tika izslēgts spirts un citi alkoholiskie dzērieni, kas ticis darīts, lai pie kriminālatbildības personas netiktu sauktas par maznozīmīga apmēra alkoholisko dzērienu pārvietošanu pāri Latvijas robežai un šo pārkāpumu izmeklēšanai netiktu tērēts nesamērīgi daudz līdzekḷu. ${ }^{18}$ Tomēr šādā gadijjumā alkoholisko dzērienu kontrabanda nekādi netika dekriminalizēta - atsakoties no šā speciālā sastāva, piemērojams atkal kḷuva KL 190. pants, kurš nesaturēja noziedzīga nodarījuma priekšmeta apmēra ierobežojumus.

Haotiskie grozijumi diemžēl diskreditēja iepriekš raksturoto likumdevēja demonstrēto izpratni par ekonomiskās un speciālo priekšmetu kontrabandas noškīiumu.

Kaut arī kontrabandas sastāvs vienmēr Krimināllikumā ir bijis ietverts, apliecinot tā nozīmību preču pareizas starptautiskas aprites aizsardzības nodrošināšanā, vienreizējs preču nelikumīgas pārvietošanas pāri valsts muitas robežai gadījums nekad nav uzskatīts par tik kaitīgu, lai kriminālatbildību paredzētu tikai par prettiesisko darbību vien - vienmēr prasìta kādu papildu kaitīgu apstākḷu iestāšanās jeb vienmēr bijis noteikts kriminālatbildības slieksnis, kas noziedzīgu rīcību atšķ̧ir no administratīvā pārkāpuma.

15 Skat. par stabila tiesiskā regulējuma nozīmi: Nikuḷceva I. Likums un tā grozījumi. Jurista Vārds, 2008. 8. aprïlis, Nr. 14.

16 Grozījumi Krimināllikumā: LV Likums. Latvijas Vēstnesis, 2007. 5. jūlijs, Nr. 107.

17 Grozijumi Krimināllikumā: LV Likums. Latvijas Vēstnesis, 2009. 9. decembris, Nr. 193.

18 Pakalne L. Par nelikumīgu alkohola pārvešanu pāri valsts robežai mazos apmēros neparedzēs kriminālatbildību. Pieejams: http://www.tm.gov.lv/lv/aktualitates/tm-informacija-presei/parnelikumigu-alkohola-parvesanu-pari-valsts-robezai-mazos-apmeros-neparedzes-kriminalatbildibu [aplūkots 2019. gada 4. maijā]. 
Sākotnēji atbildība par kontrabandu KL 190. panta pirmajā daḷā tika sasaistīta ar objektīvās puses pazīmi, kas raksturo noziedzīgā nodarījuma priekšmetu, proti, prettiesiski pārvietoto preču liels apmērs, tādējādi saglabājot Latvijas Kriminālkodeksā noteikto.

Ar 2005. gada 28. aprīḷa likumu "Grozījumi Krimināllikumā” kontrabandas pamatsastāva pazīmes "liels apmērs" vietā turpmāk kriminālatbildība saskaṇā ar KL 190. panta pirmo dalı iestājās, ja kontrabanda izdarīta atkārtoti gada laikā, domājams, reagéjot uz sistemātiskiem kontrabandas gadijjumiem. Savukārt kontrabandas preču liels apmērs turpmāk veidoja kvalificētas kontrabandas sastāvu panta otrajā daḷā. Tātad ar šiem grozijjumiem kontrabanda tika kriminalizēta neatkarīgi no konkrēta kontrabandas gadījuma objektīvā kaitīguma, ja konstatēts vismaz divu gada laikā izdarītu tādu pašu likumpārkāpumu kopums un ja iepriekšèjā reizē, pārkāpējam zinot, tie bijuši fiksēti likumā noteiktajā kārtībā (KL 23. panta piektā daḷa redakcijā līdz 2013. gada 1. aprīlim). Faktiski, būtībā kriminalizējot administratīvo pārkāpumu, kriminālatbildību noteica pārkāpuma subjektīvie faktori, precīzāk, personu raksturojošie dati. ${ }^{19}$ Tādējādi valsts, vēršoties pret personu, kurai piemērotais administratīvais sods nav bijis pietiekami efektīvs, lai turpmāk paḳ̦autos tiesiskajai kārtībai, primāri necīnās pret pārkāpumu, jo tā izdarīšanas biežums neietekmē konkrētā pārkāpuma kaitīgumu ${ }^{20}$, bet gan - pret tiesisko nihilismu.

Taču izvēlētā pieeja likumdevēja ieskatā attaisnoja sevi relatīvi īsu laiku, jo kriminālatbildības par kontrabandu nosacỉjums tika grozìts līdz ar Krimināllikuma apjomīgajiem grozījumiem saskañā ar 2012. gada 13. decembra likumu "Grozījumi Krimināllikumā"21.

Likumdevējam secinot, ka tiesībpārkāpēja personības dati ņemami vērā, individualizējot sodu vienā sankciju sistēmā, nevis - individualizējot juridiskās atbildības veidu, KL 190. panta pamatsastāva pazīmes "atkārtoti gada laikā” vietā turpmāk kriminālatbildība saskañā ar KL 190. panta pirmo daļu iestājās, ja kontrabanda izraisījusi būtisku kaitējumu. ${ }^{22}$ Savukārt Krimināllikuma pamata redakcijā noteiktajam kriminālatbildības par kontrabandu nosacỉjumam - lielam apmēram - piešķirta vēl augstāka kaitīguma pakāpe, kriminālatbildību par to nu jau paredzot seviš̌ki kvalificētajā panta trešajā daḷā.

Likumdevēja izšķiršanās, nosakot būtiski atšķirīgas maksimālās sankcijas KL 190. panta pirmajā un trešajā daḷā, rada vismaz divas problēmas. Pirmkārt, teorētiski var pastāvēt situācija, kad pāri muitas robežai tiek pārvietotas vērtīgas preces, par kurām kādu iemeslu dēḷ ir maksājami nodokḷi nelielā apmērā. Tādā gadījumā, ievērojot, ka cīṇa ar kontrabandu primāri ir vērsta pret izvairīšanos no nodokḷu nomaksas, nodarījums noteiktā mērā zaudē aktualitāti, lai gan personai būtu jāinkriminē seviš̌ci

19 Krastiņš U. Noziedzīgu nodarījumu atkārtotības un kopības teorētiski praktiskie aspekti. Jurista Vārds, 2012. gada 30. novembris, Nr. 48.

20 Saukāne L. Kriminālatbildība par atkāroti izdarītu administratīvo pārkāpumu. Jurista Vārds, 2009. 27. janvāris, Nr. 4, 2. lpp.; Krastiņš U. Krimināllikumam 10 gadi: tapšana, attīstïba un perspektīva. No: Juridiskā zinātne, 2010, Nr. 1, 21.lpp.

21 Grozījumi Krimināllikumā: LV Likums. Latvijas Vēstnesis, 2012. 27. decembris, Nr. 202.

22 Kriminālsodu politikas koncepcija, Ministru kabineta 2009. gada 9. janvāra rīkojums Nr. 6, 59. lpp. Pieejams: http://polsis.mk.gov.lv/view.do?id=2891 [aplūkots 2019. gada 5. maijā]]. 
kvalificētais kontrabandas sastāvs saskaņā ar KL 190. panta trešos dalu. Otrkārt, kad pāri muitas robežai tiek pārvietotas vērtīgas preces un netiek nomaksāti arī nodokḷi lielā apmērā, ievērojot normu konkurences noteikumus, personai būtu jāinkriminē smagākais nodarijums atbilstoši KL 190. panta trešajai daļai, ņemot vērā, ka liela apmēra zaudējumi tiek uzskatīti par pietiekamiem, lai inkriminētu noziedzīgu nodarijumu, kas izraisījis būtisku kaitējumu. ${ }^{23}$ Šādā gadījumā, izšḳiroši nepieaugot nodarījuma kaitīgumam, sankcija palielinātos 11 (!) reižu..$^{24}$

Taču arī būtisks kaitējums kā kontrabandu kriminalizējošs apstāklis likumdevēja ieskatā bija piennemams îsu laiku - ar 2015. gada 29. oktobra likumu "Grozījumi Krimināllikumā”25 lïdz šim brīdim kontrabandas krimināltiesiska ranga kaitīgumu atkal nosaka prettiesiski pārvietojamo preču vērtỉba, ko raksturo no jauna ieviestais vērtējuma jēdziens - kontrabandas preču ievērojams apmērs. Atteikšanās no būtiska kaitējuma kā sastāva objektīvās puses obligātas pazīmes noteiktu veidu noziedzīgos nodarījumos, to skaitā kontrabandā, pamatota ar mantiska kaitējuma iestāšanās nepieciešamību, lai personu sauktu pie kriminālatbildības. Akcentēts, ka šajos gadījumos, pirmkārt, nav nepieciešams kriminālatbildību saistīt ar būtisku kaitējumu, jo tas var ietvert arī nemantisku kaitējumu, un, otrkārt, būtisks kaitējums ir saistīts ar noziedzīga nodarījuma rezultātā radītu zaudējumu, nevis ar noziedzīga nodarījuma priekšmeta vērtỉbu. ${ }^{26}$ Krimināltiesību teorijā apstiprināts, ka krimināltiesību vērtējuma jēdziens "būtisks kaitējums" Krimināllikuma Sevišķās dal̦as normās izmantojams, ja noziedzīgā nodarījuma kaitīgās sekas nav iespējams precīzi noteikt vai arī tãs var būt atškịīigas katrā konkrētā situācijā. ${ }^{27}$ Ievērojot minēto un to, ka kontrabandas preces per se par tautsaimniecībai nodarītu kaitējumu tieši neliecina pretstatā kaitējumam neiekasēto nodokḷu veidā, kuru apmēru nosaka, ievērojot kontrabandas dēl nelikumīgā apritē nonākušo priekšmetu daudzumu, nav saprotams, kas liedzis par kontrabandas slieksni noteikt neiekasēto vai potenciālo nodokḷu apmēru. ${ }^{28}$ Tādēl arī patlaban pastāvošo kriminālatbildïbas slieksni nevar atzìt par optimālu - kontrabandas specifikai atbilstošu.

Krimināllikuma pamata redakcijā kontrabanda tika klasificēta kā mazāk smags noziegums, jo maksimālās negatīvās sekas personai bija paredzētas brīvības atṇemšanas soda veidā uz laiku līdz pieciem gadiem. Tādējādi tika saglabāts jau Latvijas Kriminālkodeksā noteiktais lielākais paredzētais soda veids un mērs. Turpmāk sankcijas revidētas ar 2002. gada 17. oktobra likumu "Grozījumi Krimināllikumā”29, 2004. gada

23 Hamkova D., Liholaja V. Nelikumīgas darbības ar alkoholiskajiem dzērieniem un tabakas izstrādājumiem: kvalifikācijas problemātika. Jurista Vārds, 2012. 28. augusts, Nr. 35, 15. lpp.

${ }^{24}$ Sk. plašăk: Čevers T. Kontrabandas krimināltiesiskie aspekti. Rīga: Pārdaugavas juridiskais birojs, 2015, 66.-68. lpp.

25 Grozījumi Krimināllikumā: LV Likums. Latvijas Vēstnesis, 2015. 19. novembris, Nr. 227.

26 Likumprojekta "Grozījumi Krimināllikumā” (Nr. 151/Lp12) sākotnējās ietekmes novērtējuma ziņojums (anotācija). Pieejams: http://titania.saeima.lv/LIVS12/SaeimaLIVS12.nsf/0/945D99DD5A3 969EBC2257DE3004B422E?OpenDocument [aplūkots 2019. gada 4. maijā].

27 Krastinš̌ U. Vērtējuma jēdzieni Krimināllikuma normās. Jurista Vārds. 2012. 12. jūnijs, Nr. 24, 12. lpp.

28 Sk. pretēju viedokli: Hamkova D. Profesora U. Krastina ieguldījums vērtējuma jēedziena "būtisks kaitējums" izpratnes attīstībā Latvijas krimināltiesībās. Grām.: Tiesību interpretācija un tiesību jaunrade - kā rast pareizo līdzsvaru: Latvijas Universitātes 71. zinātniskās konferences rakstu krājums. Rìga: LU Akadēmiskais apgāds, 2013, 112.lpp.

29 Grozījumi Krimināllikumā: LV Likums. Latvijas Vēstnesis, 2002. 6. novembris, Nr. 161. 
12. februāra likumu "Grozījumi Krimināllikumā”30 , 2007. gada 13. decembra likumu "Grozījumi Krimināllikumā”31. Taču būtiskākās izmainas izdarītas līdz ar kriminālatbildības sliekšņa pārdefinēšanu.

Ar 2005. gada 28. aprīịa likumu "Grozījumi Krimināllikumā", kad likumdevējs atteicās no pazīmes "liels apmērs" pamatsastāvā, pirmās daļas sankcija mīkstināta, par maksimālo sodu nosakot brīvïbas atņemšanu uz laiku līdz trim gadiem, saglabājot mazāk smaga nozieguma klasifikāciju. Savukārt kriminālatbildība par kontrabandu lielā apmērā paredzēta panta kvalificējošajā otrajā dạ̦ā, kur noteikta maksimālā sankcija - brīvibas atñemšana uz laiku no trijiem līdz astoniem gadiem, kas atbilst smaga nozieguma klasifikācijai. Tādējādi maksimālais sods par kontrabandu lielā apmērā ievērojami pieauga - vairāk nekā par pusi, proti, par trim gadiem.

Savukārt ar 2012. gada 13. decembra likumu "Grozijumi Krimināllikumā", likumdevējam atsakoties no pazīmes "atkārtoti gada laikā" pamatsastāvā, pirmās daḷas sankcija atkal mīkstināta, par maksimālo sodu nosakot brīvības atñemšanu uz laiku līdz vienam gadam, saglabājot mazāk smaga nozieguma klasifikāciju, neraugoties uz to, ka kriminālatbildība saistīta ar kaitīgu seku iestāšanos. Savukārt kriminālatbildỉba par kontrabandu lielā apmērā paredzēta nu jau seviški kvalificējošajā trešajā daļā, kur noteikta maksimālā sankcija brīiibas atnememšana uz laiku no diviem līdz 11 gadiem, kas atbilst seviškị smaga nozieguma klasifikācijai. Tādējādi maksimālais sods par kontrabandu lielā apmērā, salīdzinot ar Krimināllikuma iepriekšējo redakciju, pieaudzis vēl ievērojamāk - vēl par trim gadiem.

Toties ar 2015. gada 29. oktobra likumu "Grozījumi Krimināllikumā"32, grozot kriminālatbildības slieksni uz kontrabandas preču ievērojamu apmēru, sankcijas netika mainītas.

Jãsecina, ka likumdevējs līdz šim nav demonstrējis skaidru pozīciju par kontrabandas vispār un tās kvalificējošo pazīmju kaitīgumu, lai radìtu pārliecinošu un noturīgu regulējumu. Rodas bažas par līdz šim vispār kādu kritēriju esamību soda robežu noteikšanā, it îpaši, ievērojot pretēji vērstu tendenci, ka - par kriminalizētu kontrabandu (noziedzīgā nodarījuma pamatsastāvu) soda maksimālās robežas ir būtiski samazinātas, toties par kontrabandu lielā apmērā soda maksimālās robežas ir uzskatāmi palielinātas. Turklāt liela apmēra izpratne visu šo laiku nav mainïjusies ${ }^{33}$, lai gan šāda tipa nenoteiktos juridiskos jēdzienus juridiskajā tehnikā izmanto tieši tādēḷ, lai tiesisko regulējumu padarìtu elastīgāku un izvairìtos no grozìjumiem, korespondējot izmaiņām valsts sociāli ekonomiskajos procesos. Izvērtējot sankciju izmainas, nav konstatējams, ka to bargumu būtu ietekmējusi Latvijas Republikas dalība Eiropas Savienībā, akcentējot vietējo muitas iestāžu darba nozīmes pieaugumu nu jau visa reg̣ionālā iekšejēā tirgus aizsardzībā.

Likumdevēja nekonsekvence liek aizdomāties par valstī pastāvošo kriminalizēšanas politiku, kas būtu atsevišķas izpētes priekšmets. Kā zināms, kriminālatbildība

30 Grozījumi Krimināllikumā: LV Likums. Latvijas Vēstnesis, 2004. 3. marts, Nr. 34.

31 Grozījumi Krimināllikumā: LV Likums. Latvijas Vēstnesis, 2007. 29. decembris, Nr. 208.

32 Grozījumi Krimināllikumā: LV Likums. Latvijas Vēstnesis, 2015. 19. novembris, Nr. 227.

33 Sk.: likuma "Par Krimināllikuma spēkā stāšanās un piemērošanas kārtību" 20. pants. 
ir piemērota sociālās kontroles forma tikai nopietnāko pārkāpumu gadījumā, turklāt, lai izvairītos no kriminālatbildības mērḳu kompromitēšanas, tai ir jābūt efektīvai tai ir acīmredzami jāattur noziedzīgo nodarījumu izdarīšana, un kriminālprocesa mehānisma darbināšanā ieguldītajiem resursiem ir jāatsver noziedzīgajā nodarījumā nodarītais kaitējums, ja vien vēršanās pret konkrēto prettiesisko rīcību neietver arī zināmu simbolisku nozīmi. ${ }^{34}$

Krimināllikumā, tajā skaitā, KL 190. pantā, līdz šim izmaiņas veiktas nepamatoti bieži, noniecinot tiesiskās noteiktības principu un konkrētāk degradējot respektu pret Krimināllikumu kā sabiedrības būtiskāko vērtību sargātāju un likumsakarīgi mazinot tam uzticamību, kas ir priekšnoteikums tā ievērošanai. ${ }^{35}$ Tajā pašā laikā likumdevējs nav uzskatījis par vajadzīgu kontrabandas legāldefinīcijā nepārprotami fiksēt, ka krimināltiesiskā kārtā ir sodāma preču prettiesiska ievešana Eiropas Savienības muitas teritorijā vai izvešana no tās, n,emot vērā, ka Eiropas Savienībā pastāv vienota muitas teritorija ar visās dalībvalstīs vienādām muitošanas prasībām.

Krimināltiesību pētnieki jau tēlaini izteikušies par Krimināllikumu kā eksperimentālo lauciṇu un grozijjumu regulāro izdarīšanu tajā kā vivisekciju, uzsverot, ka izmaiņas Krimināllikumā nav bijušas izsvērtas, skaidri nedefinējot to mērḳi un nepārliecinoties par to efektivitāti. ${ }^{36}$ Turklāt bieži nav pieejamas izsludināto grozījumu anotācijas, jo attiecīgie priekšlikumi nav iesniegti likumprojekta pirmajā lasījumā, kas plašākam interesentu lokam liedz izprast konkrēto grozījumu jēgu un apgrūtina normas iztulkošanu.

\section{Kopsavilkums}

1. Jau Krimināllikuma sākotnējās redakcijas 19. nodaļu "Noziedzīgi nodarījumi tautsaimniecībā" ievadīja 190. pants "Kontrabanda”, apstiprinot šì noziedzīgā nodarījuma imanento piederību Krimināllikuma Sevišķās daļas sistēmai.

2. Krimināllikuma 190. pants ir viena no tām tiesību normām, kas uzskatāmi atklāj Latvijas Republikas tiesiskās iekārtas maiṇu, atjaunojot neatkarību, proti, kontrabandas grupas objekts ir noteikts, ievērojot tās objektīvo kaitīgumu, nevis politisku izšķiršanos un attiecīgi kriminālatbildību par kontrabandu paredzot līdztekus noziedzīgajiem nodarījumiem tautsaimniecībā, nevis - noziedzīgiem nodarijumiem pret valsti.

3. 20 gadu laikā, kopš ir stājies spēkā Krimināllikums, kontrabandas legāldefinīcijā Krimināllikuma 190. panta pirmās daḷas dispozīcijā veikti vien redakcionāli precizējumi, savukārt kriminālatbildības par kontrabandu slieksnis ir grozīts trīs reizes,

${ }^{34}$ Ashworth A. Principles of Criminal Law. Fourth Edition. Oxford: Oxford University Press, 2003, pp. 35-37.

35 Sk. par likuma autoritātes nozīmi tā ievērošanā: Šulmane D. Tiesību normu efektivitātes problemātika un aktualitāte XX un XXI gadsimta tiesību sociolog̣ijā. Promocijas darbs. Rỉga: Latvijas Universitāte, 2012. Pieejams: https://dspace.lu.lv/dspace/bitstream/handle/7/5169/29014-Dace_Sulmane_2013. pdf? sequence $=1$ \&isAllowed $=y$ [aplūkots 2019. gada 11. maijā] .

36 Liholaja V., 2009, 31. paragrāfs; Liholaja V., 2004. 
kas acīmredzami norāda uz likumdevēja nespēju noteikt šī noziedzīgā nodarījuma kaitīgumu un piemērotāko tiesību aizsardzības līdzekli cīnai ar to. Koriǵéjot Krimināllikuma 190. pantu, likumdevējs nav rūpējies par tiesiskās noteiktības principa ievērošanu.

4. Laika gaitā veiktās kontrabandas legāldefinīcijas izmaiṇas nesekmē tās satura izpratni un nevar atvieglot tās piemērošanu, n,emot vērā, ka nav ievērota juridiskās tehnikas prasībām atbilstošākā lakoniskā izteiksme, kodolīgi raksturojot prettiesiskās darbības būtību.

\section{BIBLIOGRĀFIJA}

1. Ashworth A. Principles of Criminal Law. Fourth Edition. Oxford: Oxford University Press, 2003.

2. Blūma M., Reigase A. Latvijas PSR Kriminālkodekss un tā attīstība. Rìga: Pētera Stučkas LVU Redakcijas un izdevniecibas daļa, 1972.

3. Čevers T. Kontrabandas krimināltiesiskie aspekti. Rīga: Pārdaugavas juridiskais birojs, 2015.

4. Hamkova D. Profesora U. Krastiņa ieguldïjums vērtējuma jēdziena "būtisks kaitējums” izpratnes attīstībā Latvijas krimināltiesībās. Grām.: Tiesību interpretācija un tiesību jaunrade - kā rast pareizo līdzsvaru: Latvijas Universitātes 71. zinātniskās konferences rakstu krājums. Rīga: LU Akadēmiskais apgāds, 2013, 109.-118. lpp.

5. Hamkova D., Liholaja V. Nelikumīgas darbības ar alkoholiskajiem dzērieniem un tabakas izstrādājumiem: kvalifikācijas problemātika. Jurista Vārds, 2012. 28. augusts, Nr. 35.

6. Krastiņš U. Noziedzīgu nodarījumu atkārtotības un kopības teorētiski praktiskie aspekti. Jurista Vārds, 2012. 30. novembris, Nr. 48.

7. Krastiņš U. Vērtējuma jēdzieni Krimināllikuma normās. Jurista Vārds, 2012. 12. jūnijs, Nr. 24.

8. Krastiņš U. Krimināllikumam 10 gadi: tapšana, attīstība un perspektīva. No: Juridiskā zinātne, 2010, Nr. 1, 5.-24. lpp.

9. Krastiņš U., Liholaja V., Niedre A. Krimināltiesības. Sevišķā daļa. Trešais papildinātais izdevums. U. Krastiņš (zin. red.). Rīga: Tiesu namu aǵentūra, 2009.

10. Krastiņš U., Liholaja V., Niedre A. Krimināltiesības. Vispārīgā daļa. Trešais papildinātais izdevums. U. Krastiņš (zin. red.). Rīga: Tiesu namu aǵentūra, 2008.

11. Krastiņš U., Niedre A. Krimināllikuma komentāri. 5. grāmata. Sevišķā daļa. Rīga: AFS, 1999.

12. Liholaja V. Demokrātijas paraugstunda jeb Krimināllikuma kārtējā vivisekcija. Jurista Vārds, 2004. 27. janvāris, Nr. 3. Pieejams: https://juristavards.lv/doc/83479-demokratijas-paraugstunda-jeb-kriminallikuma-karteja-vivisekcija/ [aplūkots 2019. gada 7. maijā].

13. Liholaja V. Uz Krimināllikuma desmitgadi atskatoties. Jurista Vārds, 2009. 17. novembris, Nr. 46.

14. Likumprojekta "Grozījumi Krimināllikumā” (Nr. 151/Lp12) sākotnējās ietekmes novērtējuma ziņojums (anotācija). Pieejams: http://titania.saeima.lv/LIVS12/SaeimaLIVS12.nsf/0/945D 99DD5A3969EBC2257DE3004B422E? OpenDocument [aplūkots 2019. gada 5. maijā].

15. Niedre A. Par Latvijas krimināltiesībām, tuvojoties Eiropas kritērijiem. Latvijas Vēstnesis, 2001. 9. janvāris, Nr. 4. Pieejams: https://www.vestnesis.lv/ta/id/1311 [aplūkots 2019. gada 4. maijā].

16. Nikuļceva I. Likums un tā grozïjumi. Jurista Vārds, 2008. gada 8. aprīlis, Nr. 14.

17. Pakalne L. Par nelikumīgu alkohola pārvešanu pāri valsts robežai mazos apmēros neparedzēs kriminālatbildību. Pieejams: http://www.tm.gov.lv/lv/aktualitates/tm-informacija-presei/ 
par-nelikumigu-alkohola-parvesanu-pari-valsts-robezai-mazos-apmeros-neparedzes-kriminalatbildibu [aplūkots 2019. gada 4. maijā] .

18. Saukāne L. Kriminālatbildība par atkāroti izdarītu administratīvo pārkāpumu. Jurista Vārds, 2009. gada 27. janvāris, Nr. 4.

19. Šulmane D. Tiesību normu efektivitātes problemātika un aktualitāte XX un XXI gadsimta tiesību sociologijā. Promocijas darbs. Rịga: Latvijas Universitāte, 2012. Pieejams: https://dspace.lu.lv/dspace/bitstream/handle/7/5169/29014-Dace_Sulmane_2013.pdf?sequence $=1$ \&isAllowed $=y$ [aplükots 2019. gada 11. maijā] .

\section{Likumi un normativie akti}

20. Grozījumi Krimināllikumā: LV Likums. Latvijas Vēstnesis, 2015. 19. novembris, Nr. 227.

21. Grozījumi Krimināllikumā: LV Likums. Latvijas Vēstnesis, 2012. 27. decembris, Nr. 202.

22. Grozījumi Krimināllikumā: LV Likums. Latvijas Vēstnesis, 2009. 9. decembris, Nr. 193.

23. Grozījumi Krimināllikumā: LV Likums. Latvijas Vēstnesis, 2007. 29. decembris, Nr. 208.

24. Grozījumi Krimināllikumā: LV Likums. Latvijas Vēstnesis, 2007. 5. jūlijs, Nr. 107.

25. Grozījumi Krimināllikumā: LV Likums. Latvijas Vēstnesis, 2005. 18. maijs, Nr. 78.

26. Grozījumi Krimināllikumā: LV Likums. Latvijas Vēstnesis, 2004. 3. marts, Nr. 34.

27. Grozījumi Krimināllikumā: LV Likums. Latvijas Vēstnesis, 2002. 6. novembris, Nr. 161.

28. Krimināllikums: LV Likums. Latvijas Vēstnesis, 1998. 8. jūlijs, Nr. 199/200.

29. Kriminālsodu politikas koncepcija, Ministru kabineta 2009. gada 9. janvāra rīkojums Nr. 6. Pieejams: http://polsis.mk.gov.lv/view.do?id=2891 [aplūkots 2019. gada 5. maijā].

30. Latvijas Kriminālkodekss. Rīga: Latvijas Republikas Tieslietu ministrija, 1992.

31. Latvijas Padomju Sociālistiskās Republikas Kriminālkodekss. Oficiālais teksts ar pielikumiem, kuros ievietoti pa pantiem sistematizēti materiāli. Rỉga: Avots, 1984.

32. Muitas likums: LV Likums. Latvijas Vēstnesis, 1997. 27. jūnijs, Nr. 155/156 (zaudējis spēku).

33. Par Krimināllikuma spēkā stāšanās un piemērošanas kārtību: LV Likums. Latvijas Vēstnesis, 1998. 4. novembris, Nr. 331/332. 